\title{
Pemanfaatan Kelas Maya Berbasis Proyek Terhadap Hasil Belajar Mahasiswa Universitas Triatma Mulya
}

\author{
Author: \\ Isyarotullatifah \\ Afiliation: \\ Universitas Triatma \\ Mulya
}

\section{Corresponding email \\ isyarotullatifah \\ @ triatmamulya.ac.id}

Histori Naskah:

Submit: 2022-02-04

Accepted: 2022-02-16

Published: 2022-02-16

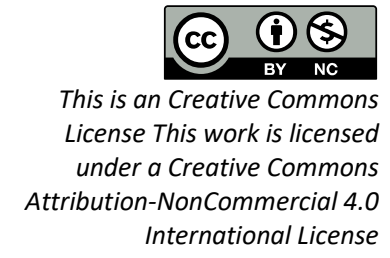

\begin{abstract}
Abstrak:
Pembelajaran saat ini dikreasikan dengan pemanfaatan media online guna menyalurkan bahan pembelajaran kepada pebelajar. Hal ini sebagai salah satu dampak pandemi yang membatasi gerak masyarakat dalam berinteraksi guna membantu menekan angka penyebaran kasus Covid-19. Pemilihan pembelajaran secara daring merupakan salah satu alternatif yang dipilih untuk mendukung terlaksananya proses pembelajaran. Tujuan dari penelitian ini adalah untuk mengetahui pengaruh pemanfaatan kelas maya berbasis proyek pada mata kuliah Ilmu Alamiah Dasar (IAD) terhadap hasil belajar mahasiswa tingkat I Universitas Triatma Mulya sebagai salah satu upaya untuk menekan penyebaran kasus Covid19 di Perguruan Tinggi. Penelitian ini merupakan penelitian eksperimen semu (quasi eksperimen) dengan desain Post Test Only Control Group Design. Populasi dalam penelitian ini merupakan seluruh mahasiswa tingkat I Universitas Triatma Mulya Tahun Akademik 2021/2022. Sampel yang digunakan yaitu mahasiswa program studi Pendidikan Bahasa Inggris sebagai kelas eksperimen dan mahasiswa program studi Pendidikan Guru Sekolah Dasar sebagai kelas kontrol, dengan jumlah 38 orang. Pengumpulan data dilakukan dengan metode tes pilihan ganda yang kemudian dianalisis dengan uji normalitas, uji homogenitas dan uji hipotesis. Penelitian ini menunjukkan adanya peningkatan hasil belajar mahasiswa terhadap mata kuliah Ilmu Alamiah Dasar. Analisis dari hasil penelitian diperoleh bahwa rata-rata post test hasil belajar yang dicapai mahasiswa pada kelompok eksperimen adalah 59,72 sedangkan rata-rata post test hasil belajar yang dicapai mahasiswa pada kelompok kontrol sebesar 47,78. Hasil ini menunjukkan bahwa hasil belajar mahasiswa yang menggunakan media pembelajaran kelas maya lebih tinggi dengan siswa yang belajar menggunakan model pembelajaran secara langsung dengan media power point. Adanya perbedaan perolehan hasil belajar mahasiswa kelompok eksperimen dengan kelompok kontrol menunjukkan bahwa pemanfaatan e-learning berbasis proyek secara tatap maya memberikan pengaruh positif terhadap hasil belajar mahasiswa tingkat I Universitas Triatma Mulya.
\end{abstract}

Kata kunci: Pembelajaran Tatap Maya, Project Based Learning

\section{Pendahuluan}

Salah satu aspek penting dalam pemberdayaan manusia adalah dengan memperhatikan aspek pendidikan. Melalui pendidikan pengembangan potensi, kepribadian, kecerdasan, keterampilan serta akhlak mulia para pebelajar dapat dibentuk dan diarahkan. Dewasa ini, sistem pendidikan di Indonesia telah mengalami kemajuan yang sangat pesat. Berbagai cara telah dikenalkan dan digunakan dalam proses pembelajaran dengan harapan pengajaran oleh pendidik akan lebih menarik dan lebih bermakna bagi peserta didiknya. Sehingga pendidik dapat menyampaikan bahan ajar secara tuntas kepada peserta didik sebagai target dari proses pembelajaran itu.

Dalam proses pembelajaran, pendidik dituntut kreatif dan inovatif dalam penyampaian pembelajaran sehingga peserta didik tidak merasa bosan. Hal ini tentu tidak terlepas dari peran pendidik dalam mengelola kelas mereka dengan baik. Dengan pengelolaan kelas yang baik, maka akan menarik minat dan kemauan para peserta didik dalam mengikuti pembelajaran yang disampaikan. Minat dan kemauan 
peserta didik dalam belajar tergantung dari bagaimana cara pendidik dalam menyampaikan bahan pelajaran. Apabila cara penyampaian bahan pelajaran dilakukan secara monoton, jelas akan membuat peserta didik jenuh untuk mengikuti pembelajaran tersebut. Karena pada dasarnya dalam pelaksanaan pembelajaran dibutuhkan metode pembelajaran yang efektif.

Sains diajarkan dengan menekankan pada proses memberikan pengalaman kepada pebelajar dalam memadukan pengetahuan awal mereka dengan pengetahuan yang sesuai konsep ilmuwan. Pengetahuan awal pebelajar yang diperoleh dari pengalaman mengamati fenomena-fenomena di lingkungan sekitar mereka memberikan latar belakang dalam membangun pengetahuan awal. Tentunya setiap pebelajar memiliki pemikiran yang berbeda-beda terhadap pengalaman yang diperoleh dalam kehidupan seharihari. Ketika pebelajar berada dalam proses pembelajaran di kelas, pendidik memfasilitasi kegiatan pembelajaran agar terbentuk konsep baru yang sesuai dengan konsep ilmuwan. Metode pembelajaran yang dipilih berperan penting dalam proses pembelajaran. Metode yang digunakan harusnya sesuai dengan tujuan yang akan dicapai. Dengan penggunaan metode pembelajaran yang tepat, diharapkan proses pembelajaran menjadi lebih efektif, pebelajar menjadi lebih aktif dan dapat berpengaruh pada hasil belajar yang lebih baik.

Berdasarkan hasil penyebaran angket yang dilakukan terhadap mahasiswa tingkat I di Universitas Triatma Mulya, diketahui bahwa kondisi saat ini dalam kegiatan pembelajaran yakni pembelajaran masih bersifat konvensional dan teacher oriented dan penggunaan sumber-sumber belajar belum difungsikan secara optimal. Pembelajaran seringkali dilaksanakan dengan memanfaatkan bantuan media power point, pemberian tugas terstruktur dan diskusi kelas. Apabila dilihat dari respon mahasiswa, banyak dari mereka lebih tertarik menggunakan media elektronik sebagai media pembelajaran karena media elektronik mudah digunakan. Di sisi lain, faktor kondisi saat ini yang membatasi pembelajaran secara tatap muka tidak jarang menjadikan pembelajaran seringnya terhambat karena keadaan masih dalam pandemi Covid-19. Peraturan pemerintah mengarahkan untuk melaksanakan pembelajaran secara daring dengan memanfaatkan beragam teknologi yang tersedia.

Pelaksanaan pembelajaran secara daring ini tidak sedikit memberikan kesan asing bagi peserta didik maupun pendidik sendiri. Kondisi yang sebelumnya sudah terbiasa dengan keadaan pembelajaran secara langsung diarahkan untuk dilaksanakan secara daring dengan melihat pertimbangan-pertimbangan lain dalam upaya menekan angka penyebaran kasus Covid-19. Melihat kondisi ini, tentu diharapkan pembelajaran tetap dapat terlaksana sesuai dengan target yang telah ditentukan, dengan tanpa mengesampingkan faktor keadaan yang perlu diperhatikan. Penelitian Sun et al., (2008) menginformasikan bahwa fleksibilitas waktu, metode pembelajaran, dan tempat dalam pembelajaran daring berpengaruh terhadap kepuasan mahasiswa terhadap pembelajaran.

Ketiadaaan penghambat fisik serta batasan ruang dan waktu menyebabkan peserta didik lebih nyaman dalam berkomunikasi Belajar secara daring menuntut mahasiswa mempersiapkan sendiri pembelajarannya, mengevaluasi, mengatur dan secara simultan mempertahankan motiviasi dalam belajar (Sun, 2014; Aina, M.,2016). Disisi lain ditemukan bahwa melalui e-learning dapat memotivasi belajar siswa dan sekaligus meningkatkan pemahaman siswa terkait materi yang dipelajarkan (Istambul, 2016). Temuan-temuan ini menunjukkan pemanfaatan e-learning dalam penerapan pembelajaran secara daring dapat menjadi alternatif yang bisa dipilih dalam menghadapi situasi pandemi seperti saat ini.

\section{Studi Literatur}

\section{A. Teori Belajar}


Belajar adalah suatu proses perubahan dari dalam kepribadian manusia dan perubahan tersebut ditampakkan dalam bentuk peningkatan kualitas dan kuantitas tingkah laku seperti peningkatan kecakapan, pengetahuan, sikap, kebiasaan, pemahaman, keterampilan, daya pikir, dan lain-lain (Hakim, 2015). Proses kegiatan pembelajaran di sekolah menuntut siswa untuk memiliki peran yang lebih aktif dan guru hanyalah sebagai pembimbing dan pengarah, selain itu pembelajaran yang telah dilaksanakan memiliki tujuan pencapaian akhir yang disebut dengan hasil belajar. Menurut Suyono (2011: 9) belajar adalah suatu aktivitas atau suatu proses untuk memperoleh pengetahuan, meningkatkan keterampilan, memperbaiki perilaku, sikap dan mengokohkan kepribadian.

Menurut Morgan menyatakan bahwa belajar adalah merupakan salah satu yang relatif tetap dari tingkah laku sebagai akibat dari pengalaman. Dengan demikian dapat diketahui bahwa belajar adalah usaha sadar yang dilakukan manusia melalui pengalaman dan latihan untuk memperoleh kemampuan baru dan merupakan perubahan tingkah laku yang relatif tetap, sebagai akibat dari latihan. Menurut Hilgard menyatakan belajar merupakan proses perbuatan yang dilakukan dengan sengaja, yang kemudian menimbulkan perubahan, yang keadaannya berbeda dari perbuatan yang ditimbulkan oleh lainnya. Dalam pengertian diatas, tidak berarti semua perubahan berarti belajar, tetapi dapat dimasukan dalam pengertian belajar yaitu, perubahan yang mengandung suatu usaha secara sadar untuk mencapai tujuan tertentu.

Beberapa teori belajar yakni: 1) Teori Belajar Behavioristik, merupakan teori dengan pandangan tentang belajar sebagai periubahan dalam tingkah laku sebagai akibat dari interaksi antara stimulus (rangsangan) dan respon (perilaku reaktif); 2) Teori Belajar Kognitivisme, teori belajar rasional. Pengetahuan sesorang diperoleh berdasraan pemikiran. Inilah yang disebut dengan filosofi rasionalisme. Teori belajar kognitif lebih mementingkan proses belajar daripada hasil belajar; 3). Teori Belajar Konstruktivisme, belajar merupakan suatu proses pembentukan pengetahuan. Pembentukan ini harus dilakukan oleh si belajar. Ia harus aktif melakukan kegiatan, aktif berpikir, menyusun konsep dan memberi makna tentang hal-hal yang sedang dipelajari; 4) Teori Belajar Connectionism, teori pembelajaran yang digunakan untuk era digital masa kini dan merupakan alternative teori pembelajaran pada abad digital.

\section{B. Model Pembelajaran Project Based Learning (PjBL)}

Project Based Learning merupakan model pembelajaran yang menjadikan proyek, kegiatan atau masalah sebagai media utama pembelajaran. Dalam model ini siswa akan bereksplorasi, melakukan penilaian, interpretasi dengan mengumpulkan dan mengintegrasikan pengetahuan baru berdasarkan pengalamannya dalam beraktifitas secara nyata. Pembelajaran ini dirancang untuk digunakan pada permasalahan kompleks sehingga siswa harus melakukan investigai untuk memahaminya. Hanafiah dan Suhana (2009: 30) mengungkapkan bahwa model pembelajaran Project Based Learning adalah pendekatan pembelajaran yang memperkenankan peserta didik untuk bekerja mandiri dalam mengkonstruksi pembelajarannya dan mengkulminasikannya dalam produk nyata.

Definisi Project Based Learning menurut The George Lucas Educational Foundation (2005) salah satunya adalah model pembelajaran yang menuntut pengajar dan atau peserta didik mengembangkan pertanyaan penuntun (a guiding question). Mengingat bahwa masing-masing peserta didik memiliki gaya belajar yang berbeda, maka Project Based Learning memberikan kesempatan kepada para peserta didik untuk menggali konten (materi) dengan menggunakan berbagai cara yang bermakna bagi dirinya, dan melakukan eksperimen secara kolaboratif. Hal ini memungkinkan setiap peserta didik pada akhirnya mampu menjawab pertanyaan penuntun.

Berdasarkan pendapat-pendapat tersebut, maka dapat dikatakan bahwa pendekatan Project Based Learning dikembangkan berdasarkan faham filsafat konstruktivisme dalam pembelajaran. 
Edu Cendikia: Jurnal Ilmiah Kependidikan

Volume: 1 | Nomor 3 | Desember 2021 | E-ISSN: 2798-365X | DOI: 10.47709/educendikia.v1i3.1364

Konstruktivisme mengembangkan atmosfer pembelajaran yang menuntut peserta didik untuk menyusun sendiri pengetahuannya (Bell, 1995: 28). Project based learning merupakan pendekatan pembelajaran yang memberikan kebebasan kepada peserta didik untuk merencanakan aktivitas belajar, melaksanakan proyek secara kolaboratif, dan pada akhirnya menghasilkan produk kerja yang dapat dipresentasikan kepada orang lain.

\section{E-Learning}

E-learning adalah teknologi informasi dan komunikasi untuk mengaktifkan siswa untuk belajar kapanpun dan dimanapun (Dahiya, 2012). E-learning merupakan pembelajaran jarak jauh yang menggunakan teknologi komputer atau biasanya disebut internet. Istilah e-learning banyak memiliki arti karena bermacam penggunaan e-learning saat ini. Pada dasarnya, e-learning memiliki dua tipe yaitu synchronous dan asynchronous. Synchronous berarti pada waktu yang sama. Proses pembelajaran terjadi pada saat yang sama antara pendidik dan peserta didik. Hal ini memungkinkan interaksi langsung antara pendidik dan peserta didik secara on line. Dalam pelaksanaan, synchronous training mengharuskan pendidik dan peserta didik mengakses internet secara bersamaan. Pendidik memberikan materi pembelajaran dalam bentuk makalah atau slide presentasi dan peserta didik dapat mendengarkan presentasi secara langsung melalui internet. Peserta didik juga dapat mengajukan pertanyaan atau komentar secara langsung ataupun melalui chat window. Synchronous training merupakan gambaran dari kelas nyata, namun bersifat maya (virtual) dan semua peserta didik terhubung melalui internet. Synchronous training sering juga disebut sebagai virtual classroom.

Pemanfaatan e-learning dengan baik dapat meningkatkan hasil pembelajaran dengan maksimal. Beberapa manfaat dari e-learning diantaranya menurut Rohmah (2016) yaitu (1) dengan adanya e-learning maka dapat mempersingkat waktu pembelajaran dan membuat biaya studi lebih ekonomis (2) E-learning mempermudah interaksi antara peserta didik dengan bahan materi, (3) Peserta didik dapat saling berbagi informasi dan dapat mengakses bahan-bahan belajar setiap saat dan berulang-ulang, dengan kondisi yang demikian itu peserta didik dapat lebih memantapkan penguasaannya terhadap materi pembelajaran(4) Dengan e-learning proses pengembangan pengetahuan tidak hanya terjadidi dalam ruangan kelas saja, tetapi dengan bantuan peralatan komputer dan jaringan, para siswa dapat secara aktif dilibatkan dalam proses belajar-mengajar.

Penerapan e-learning di perguruan tinggi diharapkan dapat memberikan manfaat antara lain (1) Adanya peningkatan interaksi mahasiswa dengan sesamanya dan dengan dosen (2) Tersedianya sumber-sumber pembelajaran yang tidak terbatas (3) E-learning yang dikembangkan secara benar akan efektif dalam meningkatkan kualitas lulusan dan kualitas perguruan tinggi (4) Terbentuknya komunitas pembelajar yang saling berinteraksi, saling memberi dan menerima serta tidak terbatas dalam satu lokasi (5) Meningkatkan kualitas dosen karena dimungkinkan menggali informasi secara lebih luas dan bahkan tidak terbatas.

\section{Kelas Maya}

E-learning dimanfaatkan dalam kelas maya sebagai upaya untuk melengkapi pembelajaran dalam rangka memperkaya materi yang diajarkan dalam kelas konvensional. Pembelajaran dengan memanfaatkan kelas maya merupakan suatu upaya untuk mendorong pembelajaran yang dilaksanakan kapan saja dan dimana saja, tanpa dibatasi oleh ruang dan waktu. Pembelajaran dalam kelas maya bukanlah secara utuh menggantikan pembelajaran tatap muka yang dilaksanakan bersama pengajar di dalam kelas, akan tetapi dengan memanfaatkan kelas maya pebelajar akan mendapatkan tambahan materi yang akan melengkapi 


\section{Edu Cendikia: Jurnal Ilmiah Kependidikan}

Volume: 1 | Nomor 3 | Desember 2021 | E-ISSN: 2798-365X | DOI: 10.47709/educendikia.v1i3.1364

pembelajaran konvensional. Pemanfaatan model pembelajaran seperti ini memberikan kesempatan bagi pebelajar untuk lebih aktif dan kreatif. Aktif dan kreatif yang dimaksudkan yakni dalam pembelajaran kelas maya, pebelajar diharapkan untuk lebih aktif dalam mencari, membaca dan memahami materi dari berbagai sumber digital yang tersedia. Dengan tujuan untuk dapat menyimpulkan, mencipta dan berbagi baik pengetahuan yang telah diperoleh maupun berupa hasil karya yang telah dibuat kepada rekan pebelajar. Selain itu, melalui pembelajaran kelas maya diharapkan memberikan kesempatan bagi pebelajar untuk mampu berdiskusi dan bekerja sama dalam kelompok secara virtual.

\section{E. Hasil Belajar}

Menurut Suprijono (2009:5-6) hasil belajar adalah pola-pola perbuatan, nilai-nilai, pengertian-pengertian, sikap-sikap, apresiasi, dan keterampilan. Merujuk pemikiran Gagne, hasil belajar berupa hal-hal berikut. (1) informasi verbal, yaitu kapabilitas mengungkapkan pengetahuan dalam bentuk bahasa, baik lisan maupun tertulis. (2) keterampilan intelektual, yaitu kemempuan mempresentasikan konsep dan lambang. Keterampilan intelektual terdiri dari kemampuan mengategorisasi, kemampuan analitis-sintetis, fakta konsep, dan mengembangkan psinsip-prinsip keilmuan. (3) strategi kognitif, yaitukecakapan menyalurkan dan mengarhkan aktivitas kognitifnya. (4) keterampilan motorik, yaitu kemampuan melakukan serangkaian gerak jasmani dalam urusan dan koordinasi sehingga terwujud otomatisme gerak jasmani. (5) sikap adalah kemampuan menerima atau menolak objek berdasarkanpenilaian terhadap objek tersebut. Menurut Lindgren (dalam Suprijono, 2009:7) hasil belajar meliputi kecakapan, informasi, pengertian dan sikap. Dengan demikian dapat disimpulkan bahwa hasil belajar merupakan perubahan perilaku secara keseluruhan seperti perubahan sikap, apresiasi, perbuatan, perubahan tingkah laku dari tidak tau menjadi tau, dari tidak mengerti menjadi mengerti bukan hanya salah satu aspek potensi kemanusiaan saja. Kemampuan tersebut dimiliki atau dikuasai oleh siswa setelah menerima pengalaman belajarnya.

\section{Metode Penelitian}

Penelitian ini memberikan perlakukan yang berbeda antara dua kelompok sampel. Kelompok pertama merupakan kelompok eksperimen yang diberikan perlakuan berupa pemanfaatan tatap maya berbasis proyek pada mata kuliah Ilmu Alamiah Dasar, kelompok kedua merupakan kelompok kontrol yang diberikan pembelajaran dengan metode konvensional secara langsung pada mata kuliah yang sama yaitu mata kuliah Ilmu Alamiah Dasar. Penelitian ini mengambil populasi seluruh mahasiswa tingkat I Universitas Triatma Mulya Tahun Akademik 2021/2022. Rancangan penelitian yang digunakan adalah penelitian eksperimen semu (quasi experimental), dengan menggunakan desain Post Test Only Control Group Design. Dalam rancangan ini pengambilan sampel dilakukan dengan menentukan kelompok kelas secara random/acak dengan jumlah 38 orang.

Tujuan penelitian ini untuk mengetahui hasil belajar mahasiswa tingkat I pada mata kuliah Ilmu Alamiah Dasar. Pengumpulan data dalam penelitian ini menggunakan metode tes. Tes hasil belajar dikembangkan disesuaikan dengan jenjang kemampuan kognitif. Tes ini kemudian dianalisis dengan uji normalitas, uji homogenitas dan uji hipotesis.

Data yang diperoleh kemudian dianalisis dengan uji-t. Sebelum dilakukan analisis uji-t, dilakukan terlebih dahulu uji prasyarat. Uji prasyarat ini dilakukan untuk membuktikan bahwa data yang dikumpulkan layak untuk dianalisis dengan statistik parametrik atau tidak. Pada penelitian ini dilakukan uji prasyarat berupa 
Edu Cendikia: Jurnal Ilmiah Kependidikan

Volume: 1 | Nomor 3 | Desember 2021 | E-ISSN: 2798-365X | DOI: 10.47709/educendikia.vli3.1364

uji normalitas dan uji homogenitas dengan menggunakan bantuan perangkat lunak SPSS dengan angka signifikan yang lebih besar dari 0,05 .

Hipotesis kemudian diuji dengan menggunakan uji-t. Uji-t ini digunakan untuk menguji hasil post test kelompok eksperimen dan kelompok kontrol. Pengujain uji-t secara manual untuk sampel yang tidak berkorelasi terdiri dari dua jenis persamaan yang dapat digunakan, yaitu separated vaians dan polled varians.

Rumus Separated Varians:

$t=\frac{\overline{X_{1}}-\overline{X_{2}}}{\sqrt{\left(\frac{s_{1}^{2}}{n_{1}}+\frac{s_{2}^{2}}{n_{2}}\right)}}$

Rumus Polled Varians:

$t=\frac{\overline{X_{1}}-\overline{X_{2}}}{\sqrt{\frac{\left(n_{1}-1\right) s_{1}^{2}+\left(n_{2}-1\right) s_{2}^{2}}{n_{1}+n_{2}-2}}\left(\frac{1}{n_{1}}+\frac{1}{n_{2}}\right)}$

Keterangan:

$\overline{X_{1}} \quad$ : Nilai rata-rata skor kelompok eksperimen

$\overline{X_{2}} \quad$ : Nilai rata-rata skor kelompok kontrol

$\mathrm{n}_{1} \quad$ : Banyaknya mahasiswa kelompok eksperimen

$\mathrm{n}_{2} \quad$ : Banyaknya mahasiswa kelompok kontrol

$s_{1}^{2} \quad$ : varians kelompok eksperimen

$s_{2}^{2} \quad$ : varians kelompok kontrol

Menurut Sugiyono (Koyan, 2012:41) ketentuan untuk menggunakan rumus t-tes di atas adalah sebagai berikut:

1. Bila jumlah siswa $\mathrm{n}_{1}=\mathrm{n}_{2}$, dan varian homogen maka dapat digunakan rumus t-test baik untuk Separated maupun Polled Varian. Untuk melihat harga t-tabel digunakan $\mathrm{dk}=\mathrm{n}_{1}+\mathrm{n}_{2}-2$

2. Bila $\mathrm{n}_{1} \neq \mathrm{n}_{2}$, varian homogen dapat digunakan rumus t-test dengan Polled Varian. Derajad kebebasan $\mathrm{dk})=\mathrm{n}_{1}+\mathrm{n}_{2}-2$

3. Bila $\mathrm{n}_{1}=\mathrm{n}_{2}$ varian tidak homogen, dapat digunakan rumus t-test dengan Separated Varian dan Polled Varian. Dengan $\mathrm{dk}=\mathrm{n}_{1}-1$ atau $\mathrm{n}_{2}-1$.

4. Bila $\mathrm{n}_{1} \neq \mathrm{n}_{2}$, varian tidak homogen untuk ini digunakan t-test dengan Separated Varian. Harga $\mathrm{t}$ sebagai pengganti t-tabel dihitung dari selisih harga $\mathrm{t}$-tabel dengan $\mathrm{dk}\left(\mathrm{n}_{1}-1\right)$ dan $\mathrm{dk}\left(\mathrm{n}_{2}-1\right)$ dibagi dua, dan kemudian ditambahkan dengan harga t yang terkecil.

Untuk mendapatkan hasil yang lebih akurat analisis uji-t dilakukan dnegan bantuan perangkat lunak SPSS. Apabila thitung lebih besar daripada $\mathrm{t}_{\text {tabel }}\left(\mathrm{t}_{\text {hitung }}>\mathrm{t}_{\text {tabel }}\right.$ ), maka terdapat perbedaan yang signifikan 
Edu Cendikia: Jurnal Ilmiah Kependidikan

Volume: 1 | Nomor 3 | Desember 2021 | E-ISSN: 2798-365X | DOI: 10.47709/educendikia.v1i3.1364

antara kedua variabel atau kelompok sampel. Apabila $t_{\text {hitung }}$ lebih kecil dari $t_{\text {tabel }}\left(t_{\text {hitung }}<t_{\text {tabel }}\right)$ maka tidak terdapat perbedaan yang signifikan antara kedua variabel atau kelompok sampel.

\section{Hasil}

Data yang diperoleh dalam penelitian ini merupakan hasil belajar mahasiswa (post test) dari kelompok eksperimen dan juga kelompok kontrol. Gambaran tentang hasil tes belajar mahasiswa (post test) disajikan melalui deskripsi data.

Tabel 1. Kategori rentangan interval data hasil post test kelompok eksperimen dan kelompok kontrol

\begin{tabular}{cl}
\hline Rentang Skor & \multicolumn{1}{c}{ Klasifikasi } \\
\hline $60 \leq X \leq 75$ & Sangat Tinggi \\
\hline $50 \leq X \leq 60$ & Tinggi \\
\hline $40 \leq X \leq 50$ & Sedang \\
\hline $30 \leq X \leq 40$ & Rendah \\
\hline $15 \leq X \leq 30$ & Sangat Rendah \\
\hline
\end{tabular}

Berdasarkan hasil pengukuran data hasil post test yang berjumlah 15 butir soal terhadap kelompok eksperimen menunjukkan bahwa skor tertinggi adalah 70 dan skor terendah adalah 45. Rata-rata skor hasil belajar yang diperoleh kelompok eksperimen dengan pemanfaatan kelas maya berbasis proyek adalah 59,72 berada pada interval $50 \leq X \leq 60$. Berdasarkan tabel kategori di atas, dapat disimpulkan bahwa hasil belajar mahasiswa yang memanfaatkan kelas maya berbasis proyek termasuk pada kategori "tinggi". Pada kelompok kontrol rata-rata skor hasil belajar yang diperoleh adalah sebesar 47,78, berada pada interval $40 \leq X \leq 50$. Berdasarkan tabel kategori rentangan interval, dapat disimpulkan bahwa hasil belajar mahasiswa tanpa memanfaatkan kelas maya berbasis proyek masuk pada kategori "sedang".

\section{Pembahasan}

Hasil penelitian menunjukkan adanya perbedaan rata-rata hasil post-test hasil belajar yang dicapai mahasiswa pada kelompok eksperimen dan pada kelompok kontrol. Pada kelompok eksperimen dicapai hasil belajar rata-rata mahasiswa adalah 59,72 sedangkan pada kelompok kontrol hasil belajar rata-rata mahasiswa adalah 47,78. Temuan ini menunjukkan bahwa terdapat hasil belajar yang lebih tinggi pada mata kuliah Ilmu Alamiah Dasar antara mahasiswa yang belajar dengan memanfaatkan media pembelajaran kelas maya berbasis proyek dengan mahasiswa yang belajar menggunakan metode langsung berbantuan media pembelajaran power point.

Berdasarkan penemuan yang diperoleh baik dari analisis deskriptif maupun berdasrakan hasil analisis ujit, dapat diambil keputusan bahwa pemanfaatan kelas maya berbasis proyek memberikan pengaruh yang lebih baik dibandingkan dengan pembelajaran tanpa menggunakan kelas maya berbasis proyek. Berdasarkan pertimbangan teoritis dan operasional, maka implikasi penelitian ini apabila dilihat dari teori belajar konstruktivisme adalah proses belajar dan pembelajaran di kelas. Mahasiswa dapat mengaplikasikan ide-ide mereka sendiri, mahasiswa harus mengkonstruksikan pengetahuan mereka sendiri sehingga hasil belajar dapat dicapai dengan lebih baik. Berdasarkan hal ini, pemanfaatan media ajar yang digunakan dapat membantu ketercapaian hasil belajar dengan lebih baik khususnya pada mata kuliah Ilmu Alamiah Dasar. Selain hasil yang diperoleh melalui uji ini, diperoleh hasil lain secara deskriptif yang dapat memberikan gambaran respon mahasiswa terhadap pemanfaatan kelas maya yang termasuk dalam kategori positif. Keadaan seperti ini dapat dijadikan sebagai modal untuk menciptakan 
Edu Cendikia: Jurnal Ilmiah Kependidikan

Volume: 1 | Nomor 3 | Desember 2021 | E-ISSN: 2798-365X | DOI: 10.47709/educendikia.vli3.1364

suasana belajar yang lebih efektif agar dapat meningkatkan hasil belajar mahasiswa yang lebih tinggi. Pemanfaatan kelas maya berbasis proyek memberikan pengaruh yang lebih baik daripada kelas yang menggunakan metode pembelajaran secara langsung dengan bantuan media power point. Penggunaan kelas maya ini juga dirancang agar mahasiswa dapat lebih mandiri dan aktif dalam proses pembelajaran, sehingga proses pembelajaran menjadi lebih terstruktur dan terarah.

\section{Kesimpulan}

Berdasarkan hasil penelitian dan pembahasan, dapat disimpulkan sebagai berikut. Berdasarkan hasil penelitian dan pembahasan diketahui bahwa terdapat perbedaan hasil belajar yang signifikan antara mahasiswa yang belajar dengan menggunakan kelas maya berbasis proyek dengan mahasiswa yang belajar tanpa menggunakan kelas maya berbasis proyek. Dengan demikian, penerapan kelas maya berbasis proyek dapat memberikan pengaruh positif terhadap hasil belajar mahasiswa tingkat I di Universitas Triatma Mulya. Hasil ini menunjukkan bahwa mahasiswa yang belajar dengan memanfaatkan kelas maya berbasis proyek memperoleh hasil belajar yang lebih baik daripada mahasiswa yang menggunakan pembelajaran konvensional. Bedasarkan hasil penelitian dapat diajukan saran guna mengingkatkan kualitas pembelajaran pada mata kuliah lain sejenis yakni kepada peneliti lain yang membaca penelitian ini dan bermaksud mengembangkan hasil temuan lebih lanjut, diharapkan dapat melakukan penelitian yang lebih baik dengan menggunakan sampel lebih banyak, sehingga hasilnya akan lebih luas dan lebih terukur keakuratannya. Disisi lain, penggunaan model pembelajaran lain sebagai kolaborasi pemanfaatan kelas maya dirasa menjadi alternatif lain yang dirasa baik dan dapat dikembangkan untuk diketahui pengaruhnya kepada sampel penelitian.

\section{Referensi}

Arikunto, S. (2005). Managemen Penelitian. Jakarta: PT. Rineka Cipta.

Azwar, S. (2012). Reliabilitas dan Validitas. Yogyakarta: Pustaka Pelajar

Belawati, T. (2006). Pengembangan Bahan Ajar. Jakarta: Universitas Terbuka.

Bell, B.F. (1995). Children's Science, Contructivism and learning in science. Victoria: Deakin University Pers.

Hakim, A.B. (2016). Efektifitas Penggunaan E-Learning Moodle, Google Classroom Dan Edmodo. ISTATEMENT: Information System and Technology Management. 2(1), 1-6.

Hakim, T. (2005). Belajar Secara Efektif. Jakarta: Pustaka Pembangunan Swadaya Nusantara.

Hanafiah, N. \& Cucu, S. (2009). Konsep strategi pembelajaran. Bandung: PT. Refika Aditama.

Istambul, M. R. (2016). E-learning design activity to improve student's know-ledge and skills: A case study of database design courses. International Journal of Information and Education Technology. 6(6). 432-429.

Koyan, I W. (2012). Statistik Pendidikan Teknik Analisis Data Kuantitatif. Bali: Universitas Pendidikan Ganesha Press.

Munir. (2009). Pembelajaran Jarak Jauh: Berasis Teknologi Informasi dan Komunikasi. Bandung: CV. Alvabeta. 
Edu Cendikia: Jurnal Ilmiah Kependidikan

Volume: 1 | Nomor 3 | Desember 2021 | E-ISSN: 2798-365X | DOI: 10.47709/educendikia.v1i3.1364

Rusman. 2010. Model-model Pembelajaran Mengembangkan Profesionalisme Guru. Jakarta: Rajawali Press.

Sadiman, et.al. (2005). Media Pendidikan. Jakarta: PT Raja Grafindo Persada.

Sun, P. C., Tsai, R. J., Finger, G., Chen, Y. Y., \& Yeh, D. (2008). What drives a successful eLearning? An empirical investigation of the critical factors influencing learner satisfaction. Computers and Education. 50(4):1183-1202

Sun, S. Y. H. (2014). Learner perspectives on fully online language learning. Distance Education. 35(1), $18-42$.

Suprijono. (2009). Cooperatif Learning. Yogyakarta: Pustaka Pelajar.

Suyono, H. (2011). Belajar dan Pembelajaran. Bandung: Remaja Rosda Karya.

Syaifurahman. 2013. Manajemen dalam Pembelajaran. Jakarta: PT indeks.

The George Lucas Educational Foundation. (2005). Instructional Module Project Based Learning. http://www.edutopia.org/modules/PBL/whatpbl.php 